\title{
Remediation of DDT and Its Metabolites in Contaminated Sediment
}

\author{
Sandip Chattopadhyay ${ }^{1} \cdot$ Devamita Chattopadhyay ${ }^{2}$
}

Published online: 26 November 2015

(C) Springer International Publishing AG 2015

\begin{abstract}
Chlorinated pesticides and chlorinated organics can be transformed or partially degraded in sediments under appropriate environmental conditions. Although 1,1,1-trichloro2,2-bis[p-chlorophenyl] ethane (DDT) is very persistent in the environment, 1,1-dichloro-2,2-bis(p-chlorophenyl)ethylene (DDE), a degradation product of DDT, is generally the constituent most widely detected in the environment and DDE is also resistant to further biotransformation. DDT and its degradation products (DDTR) may be transported from one medium to another by sorption, bioaccumulation, dissolution, or volatilization. In sediments, DDT strongly adheres to suspended particles, but once metabolized, DDE, the primary product, is slightly soluble in water. The major migration process for DDTR in sediment-water systems is sorption to sediment or other organic matter and the primary distribution route is the transportation of the particulates to which the compound is bound. Understanding the fate and transport of DDTR in the natural environment based on its specific characteristics is important in determining appropriate remediation option. Common DDT-contaminated sediment remediation options include dredging, capping, and natural attenuation. Sediment washing and phytoremediation have also been used in contaminated sites. Dredging is the most common sediment remediation option to remove the contaminated benthic
\end{abstract}

This article is part of the Topical Collection on Sediment and Other Pollutions

Sandip Chattopadhyay

sandip_chattopad@hotmail.com

1 Tetra Tech, Inc., 250 W. Court Street, Suite \# 200W, Cincinnati, OH 45202, USA

2 GHD Services, Inc., 9033 Meridian Way, West Chester, OH 45069 , USA sediments but often suffers from technical limitations like incomplete removal, unfavorable site conditions, sediment resuspension, and disposal issues. Capping is an in situ, lowcost remediation option for immobilization of DDT in several contaminated sediment sites. Natural or anthropogenic materials containing reactive ingredients, as distinct from a conventional sand or gravel cap, involve placing reactive materials as part of the cap matrix to increase sorption, and to enhance chemical reactivity with DDTR, or accelerate degradation. Natural attenuation can treat the DDT-contaminated sediment, but the time frame for complete remediation may be relatively long. Addition of suitable co-metabolites and acclimatized microorganisms to DDTR-contaminated sediment and alteration of sediment-water micro-environment by manipulating soil $\mathrm{pH}$, moisture content, and other chemical conditions may result in degradation of DDTR associated with sediments at rates faster than the natural attenuation rate.

Keywords DDT · Sorption · Remediation · Fate and transport $\cdot$ Sediment quality

\section{Introduction}

Dichlorodiphenyltrichloroethane (DDT) (also known as 1, 1,1-trichloro-2,2-bis[p-chlorophenyl]ethane, $\mathrm{p}, \mathrm{p}$-DDT, or $4,4^{\prime}$-DDT) is an organochlorine pesticide, and is regularly found in waters near fruit orchards, as it was used widely to control pests starting in the mid-1940s. In 1958, the US Department of Agriculture began a program to phase out DDT due to concerns about its persistence in the environment and toxicity to non-target organisms [96]. Use declined steadily until 1972, when the US Environmental Protection Agency (EPA) banned DDT for all uses, except for emergencies. The 4,4'-DDT can persist in the 
environment for decades, along with the primary aerobic metabolite 1,1-dichloro-2,2-bis(p-chlorophenyl)ethylene $(4,4 '-D D E)$ and anaerobic breakdown product 1,1 dichloro-2,2-bis(p-chlorophenyl)ethane (4,4'-DDD). DDT and its degradation compounds (DDTR) are classified by EPA under the Clean Water Act as priority pollutants.

Their persistence is due to low vapor pressure and resistance to further degradation. DDT sorbs to sediments and particulate matter in the aquatic environment due to their low water solubility and high affinity for solids, especially solids with a high organic carbon content. Transport of DDT to surface water and sediment systems is often associated with erosion of contaminated soils [90]. Regardless of the success observed for DDT remediation of soil in Superfund sites (Aberdeen Pesticides Dumps in North Carolina, Fort Wainwright in Alaska, Montrose and Del Amo Superfund sites in California, and others) by using various technologies (such as white rot fungi bioremediation, enzyme degradation, mediated electrochemical oxidation, photochemically enhanced microbial degradation) [36, 53, 55, 98, 109], translation of these successes to an aquatic environment is challenging and is likely not practical. The focus of this paper is to evaluate successful remediation options for DDT in the sediment-water environment.

Although banned over 40 years ago, DDT continues to be present at relatively high concentrations in the sediment and water bodies in the USA including Wenatchee River, Washington [1]; St. Johns River basin, Florida [75]; Hudson River, New York [78]; Pine River, Michigan [30, 31]; Newark Bay, New Jersey, and its major tributaries (Passaic River, Hackensack River, Newark Bay, Arthur Kill, Elizabeth River, and Kill Van Kull) [44]; Tombigbee River, Alabama [97]; Palos Verdes Peninsula, California [43]; and others. Ruus et al. [84] reported that unexpected increase in DDTconcentrations in various media (about two orders of magnitude higher concentrations in mussels than background) despite the discontinuation of use, is due to the shifts in climatic parameters, as well as increased amounts of sediment dissolved organic carbon (DOC) that contribute to increased transport of DDT sorbed to humic-rich substrates and wash-out to the contaminated sediment sites. Positive correlations between the DDT loads and total suspended solids (TSS), total organic carbon (TOC), and fine-grained sediment in water samples have been found in several DDT-contaminated sediment sites [46, 108]. The occurrence, distribution, and remediation of the DDTR as the primary contaminant of concern or a co-contaminant at contaminated sediment sites are of wide interest because they can persist in the environment and can accumulate in the tissues of fish, other wildlife, and humans [28, 53, 61, 98].

\section{Identification, Fate, and Transport/Characteristics of DDTR in Sediment-Water System}

The fate and transport of DDT in sediment-water system is dependent on various site-specific characteristics, environmental conditions, and geo-technical characteristics including the topography, geology, tidal influences, and sediment composition. DDT can be transformed or partially degraded in sediments under appropriate environmental conditions. Unfortunately, the degradation products are as toxic and persistent as the original pesticides. The two most common degradation products of DDT are DDE and DDD. Technical grade DDT is a mixture of three forms: p,p'-DDT ( $85 \%), o, p^{\prime}-D D T$ $(15 \%)$, and o,o'-DDT (trace amounts). All of these forms of DDT are white, crystalline, tasteless, and almost odorless solids. DDT is degraded to DDE under aerobic conditions and to DDD in anoxic systems [26]. Although various DDT constituents may be found in sediments, DDE is generally the constituent most widely detected in the environment and the constituent that is most resistant to further biotransformation. DDTR represent a contamination risk for the surface water and groundwater systems, especially the polar metabolite 2 , 2-bis(chlorophenyl)acetic acid (DDA), a water-soluble degradation product of DDT residue and a dominant DDT derivative in DDT-contaminated sediment sites [104]. These DDTR can be divided into three groups: (a) free available, (b) easily releasable, and (c) hardly releasable fractions [37]. The free available compounds are sorbed on sediment particles by van der Waals forces or ionic attraction. The easily releasable compounds remobilize by hydrolysis processes, which occur under natural conditions. The hardly releasable fractions are covalently bound and require a higher bond cleavage (ether/ester bond cleavage and carbon-carbon bond cleavage) enthalpy for remobilization.

DDT and its principal metabolites (DDD and DDE) are organochlorine compounds that are persistent in the environment due to low vapor pressure, lipophilicity, and resistance to degradation and photo-oxidation [3, 4, 108]. The half-life of DDT varies between 2 and 25 years [3,24]. These compounds can become more strongly associated with sediment components over time and become recalcitrant to degradation. Halflives for DDTR are estimated to be shorter (almost half) in Australia where cold and wet winters and hot and dry summers accelerate the aging process. Despite low vapor pressures, volatility of DDTR compounds is responsible for its migration from temperate zones in low to mid latitudes to the high-latitude zones, such as the Arctic and Antarctic and persists longer in these colder climatic regions [5]. Photooxidation of DDT is known to occur in epilimnion of stratified lakes; however, hydrolysis is not known to occur [4]. Direct photolysis of DDT by ultraviolet radiation yielded DDE; DDD; p,p'-dichlorobenzophenone (DDCO); and hydrogen chloride. Biodegradation may occur under both aerobic and 
anaerobic conditions by microorganisms including fungi, algae, and mixed microbial populations [67].

The fate and transport of DDT in sediment-water systems at the Marine Corps Base Quantico, Virginia, as a representative contaminated site is shown in Fig. 1. A slow but continuous decrease in DDTR concentrations is generally observed in contaminated sediments, resulting from erosion, migration, plant and animal uptake, photodegradation, and biodegradation [2]. The major fate process for DDT in sediment-water systems is sorption to sediment or other organic matter and the primary loss route is the transportation of the particulates to which the compound is bound [4].

\section{Levels Detected in the Sediment-Water Environment}

The EPA has classified DDT as a class II, moderately toxic chemical. DDT concentrations in sediment often exceed a few milligrams per kilogram and sometimes reach concentrations as high as a few grams per kilogram [34]. Nearshore depositional areas at 18 sites in San Joaquin Valley, California, showed concentrations as high as 1000 to $2000 \mu \mathrm{g} / \mathrm{kg}$ of DDTR, but typical concentrations were approximately $10 \mu \mathrm{g} / \mathrm{kg}$ in most locations [57]. Long et al. [64] reported that the concentrations of total DDT in the Newbridge Pond, Long
Island, New York, ranged from 3.5 to $4460 \mu \mathrm{g} / \mathrm{kg}$. The concentrations of total DDT ranged from 233 to $6100 \mu \mathrm{g} / \mathrm{kg}$ at various sediment sample locations Abraham's Creek, Marine Corps Base, Quantico, Virginia, and the highest concentration of total DDTR was $12,050 \mu \mathrm{g} / \mathrm{kg}$ at 12 to 18 -in. depth [7]. BASF manufactured DDT at the McIntosh, Alabama during 1952 to 1974 . DDTR concentrations in sediments ranged from 0.06 to $2.68 \mathrm{mg} / \mathrm{kg}$ in the Olin McIntosh Operable Unit 2 Basin at the downstream of the BASF facility due to indirect discharge through run off and flood events [29].

In addition to soil and sediment residues, DDT and its breakdown products can still be found in water and air. The total DDT concentration values observed in various rivers were higher than the WHO guideline value of $2 \mu \mathrm{g} / \mathrm{L}$ in drinking water $[94,103]$. Total concentrations of DDTR in air (gas + particle) were reported to be 170 to $240 \mathrm{pg} / \mathrm{m}^{3}$ in the Pearl River Delta, China [112]. Hermanson et al. [51] reported concentrations of the $\mathrm{p}, \mathrm{p}^{\prime}$-isomers at four sites in Michigan were 1910 (DDT), 5420 (DDE), and 113 (DDD)pg/m³ and for o, p'DDT, DDE, and DDD were 687,313 , and $80 \mathrm{pg} / \mathrm{m}^{3}$. As previously described, DDTR are highly non-polar lipophilic compounds that have a low aqueous solubility ranging from $0.025 \mathrm{mg} / \mathrm{L}$ for p,p'-DDT to $0.14 \mathrm{mg} / \mathrm{L}$ for o,p'-DDE [5]. They also have a very high affinity for organic matter, with an organic carbon partition coefficient (Koc, unit dimensionless) ranging from 104.70 for $\mathrm{p}, \mathrm{p}^{\prime}$-DDE to 105.35 for o,p'-DDT

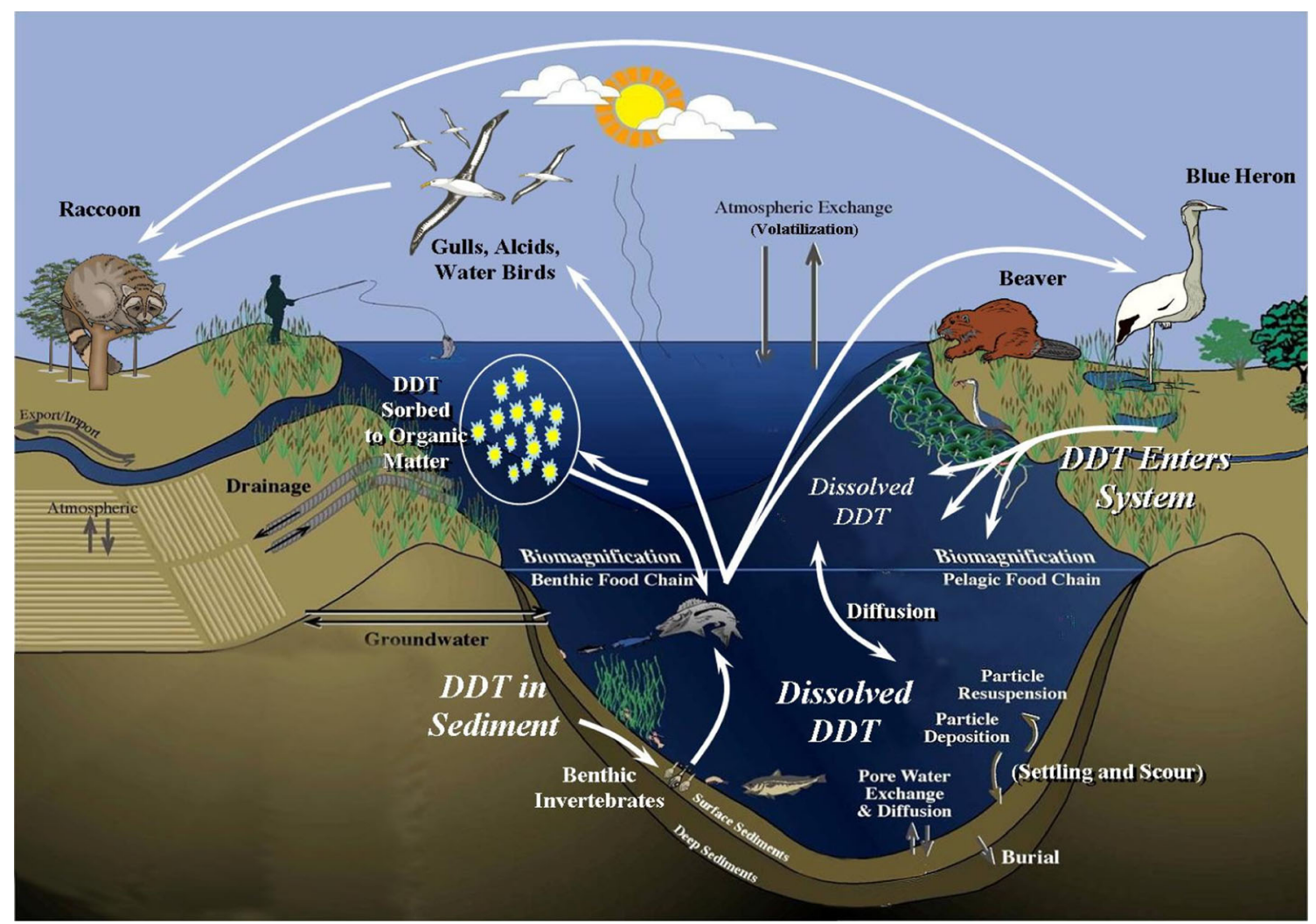

Fig. 1 Fate and transport of DDT in sediment-water system at the marine corps base Quantico, Virginia 
[5]. Hence, DDTR accumulates and tends to remain longer in sediments and other colloidal particles with high organic matter contents.

\section{Environmental Risk and Toxicity}

Studies have found that plants, fish, mammals, and birds, as well as phytoplankton and zooplankton in an aquatic environment, bioaccumulate DDT. Laboratory studies showed that $\log$ bioconcentration factors (BCFs) for DDT in aquatic organisms ranged from 3.08 to 6.65 and that for DDE ranged from 4.80 to 5.26 [26]. ATSDR [4] reported that the BCF of DDT in rainbow trouts can be approximately 12,000 , while the estimated BCF in humans is above 1650. A study completed in northern Canada found that biota living in the bottom of the sea had much higher levels of total DDT than biota living in the open sea. This is likely a result of DDT adsorption onto particulates that settled into bottom sediments. The ringnecked seal apparently biomagnified DDT, suggesting that biomagnification is possible in other species as well [4]. Others have also found DDT biomagnification from sediment to mosquito fish, and a study completed in Lake Michigan indicated that DDE biomagnified 28.7 times from phytoplankton to fish and 21 times from sediments to amphipods [4].

DDT is highly toxic to many aquatic invertebrate species. Reported 96-h lethal concentrations that kill $50 \%$ of test subjects (LC50s) in various aquatic invertebrates (e.g., stoneflies, midges, crayfish, sow bugs) range from 0.18 to $7.0 \mu \mathrm{g} / \mathrm{L}$. Forty-eight-hour LC50s are $4.7 \mu \mathrm{g} / \mathrm{L}$ for daphnids (Ceriodaphnia dubia) and $15 \mu \mathrm{g} / \mathrm{L}$ for sea shrimp [54]. DDT is also highly toxic to fish species. Reported 96-h LC50s are less than $10 \mu \mathrm{g} / \mathrm{L}$ in coho salmon $(4.0 \mu \mathrm{g} / \mathrm{L})$, rainbow trout $(8.7 \mu \mathrm{g} / \mathrm{L})$, bluegill sunfish $(8.6 \mu \mathrm{g} / \mathrm{L})$, and largemouth bass $(1.5 \mu \mathrm{g} / \mathrm{L})$; LC50s for fathead minnow and channel catfish were found to be 21.5 and $12.2 \mu \mathrm{g} / \mathrm{L}$, respectively [54]. DDT is also moderately toxic to some amphibian species and larval stages appear to be more susceptible than adults [108]. DDT may bioaccumulate significantly in fish and other aquatic species, leading to long-term exposure. This occurs mainly through uptake from sediments and water into aquatic flora and fauna. A half-time for elimination of DDT from rainbow trout was estimated to be 160 days [108].

Short-term exposure to high doses of DDT primarily affects the human central nervous system. Accidental ingestion by humans has caused excitability, tremors, and seizures. Exposure has also caused rashes or irritation to the eyes, nose, and throat. Long-term exposure to low doses of DDT has produced changes in liver enzyme activity. Studies in laboratory animals have also confirmed effects on the nervous system, and have demonstrated increased occurrence of liver tumors and reproductive impairment [4]. In 1992, the EPA promulgated the National Toxics Rule (NTR, 40 CFR 131.36) which established numeric, chemical-specific water quality criteria for all priority pollutants in order to bring states into compliance with the Clean Water Act. NTR human health criteria were derived from acceptable levels of fish tissue and water consumption, although water ingestion is considered a negligible DDT exposure pathway for humans. Prior to 2000, the Food and Drug Administration (FDA) set the action level for DDT at $5 \mathrm{mg} / \mathrm{kg}$ for restricting fish consumption. In 2000, the EPA adopted guidelines to be used for the evaluation of impacts for fisheries. In 2001, the Mississippi Department of Environmental Quality determined the need to restrict fish consumption if DDT levels exceed $1 \mathrm{mg} / \mathrm{kg}$. Acceptable fish tissue concentrations, based on a one-in-one-million excess lifetime cancer risk, are $32 \mathrm{ng} / \mathrm{g}$ for 4,4'-DDE and 4,4'-DDT, and $45 \mathrm{ng} / \mathrm{g}$ for $4,4^{\prime}-\mathrm{DDD}$. The NTR used a bioconcentration factor of 53,600 to translate acceptable tissue concentrations to criteria for water, which are $0.59 \mathrm{ng} / \mathrm{L}$ for $4,4^{\prime}-\mathrm{DDE}$ and 4 , 4'-DDT, and $0.83 \mathrm{ng} / \mathrm{L}$ for 4,4 '-DDD.

\section{Sediment Quality Guidelines}

Development of sediment quality guidelines is an evolving science. There is a continued need for guidelines to be supported by site-specific conditions due to various factors including variable environmental and site-specific factors that control the sequestering, release, and bioavailability of DDTR in sediments; the effects of varying mixtures of cocontaminants; and the variable sensitivities and exposure and uptake routes of benthic macroinvertebrates to DDTR. In addition, biological criteria based on specific toxicity tests and identified endpoints (e.g., mortality, growth, and reproduction to the test organisms) and benthic community study metrics should be established and used, as appropriate, in evaluating sediment quality. Table 1 is a compilation of sediment quality guidelines for DDTR from different sources. Sediment quality guidelines developed by Long et al. [63] were based on comparisons of effects of various organisms exposed to DDTcontaminated sediments and sediment characteristics. The distribution of effects data were evaluated to develop two guidelines: (a) an effects-range low (ERL) guideline, the lower 10th percentile of the effects data, and (b) an effects-range-median (ERM) guideline, the 50th percentile of the effects data. Concentrations below the ERL typically represent where adverse effects would rarely occur. Concentrations between the ERL and the ERM represent conditions in which adverse effect may occur, and concentrations above the ERM represent conditions in which adverse effects are likely to occur. However, these estimates are based on site-specific conditions and should not be used to predict DDT toxicity.

Oak Ridge National Laboratory (ORNL) in Tennessee developed sediment screening criteria based on equilibrium 


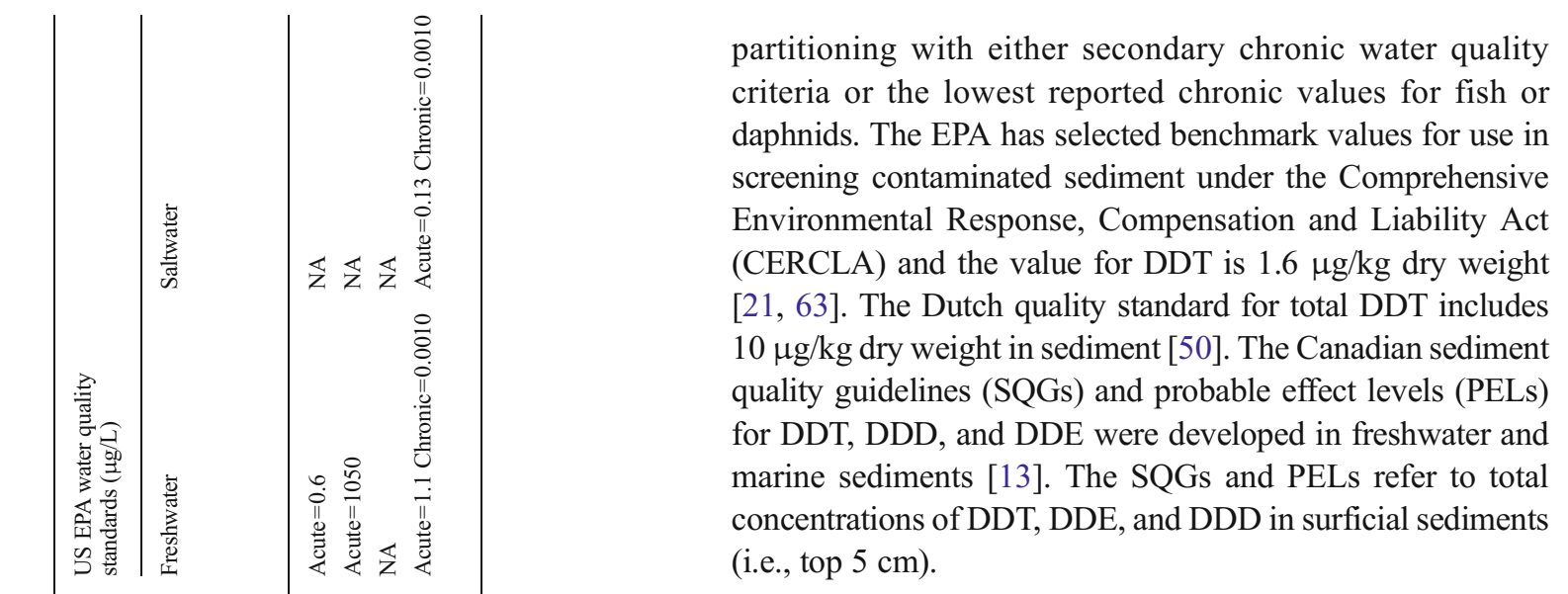

Remediation of DDT-Contaminated Sediment

Presently, four basic options for remediation of contaminated sediment and floodplain sediment in relation to water body/channel condition exist as follows: (a) containment in-place, (b) treatment in-place, (c) removal and containment, and (d) removal and treatment. Existing technologies for remediating DDT-contaminated sites focus primarily on highly polluted areas and may not be suitable for remediating vast, diffusely polluted sediment areas where pollutants occur at relatively low concentrations. Common DDT-contaminated sediment remediation strategies include dredging, capping, and natural attenuation. Sediment washing and phytoremediation have also been used. Since each remedial action can result in a change in the physical, chemical, and biological conditions of the sediment, it is expected that the degradation and transport properties of DDT could change as the result of implementing a remedial action. The following sections provide discussion of five remediation options that have been considered in several DDTR contaminated sediment sites. A summary of applicability, advantages, limitations, and cost considerations of selected remediation options is shown in Table 2.

\section{Dredging}

Removal via dredging is the most common sediment remedial action but often suffers from technical limitations like incomplete removal, unfavorable site conditions, sediment resuspension, and sediment disposal [6]. Nadeau et al. [69], Gustavson et al. [45] and the National Research Council [72] described the difficulties in site characterization and in estimating the effects of dredging, and uncertainties in predicting the future transport and effects of contaminated sediment. The Lauritzen Canal, a portion of San Francisco Bay, California, was heavily contaminated with DDT and other pesticides as a result of operation of a pesticide formulator. The contaminated 


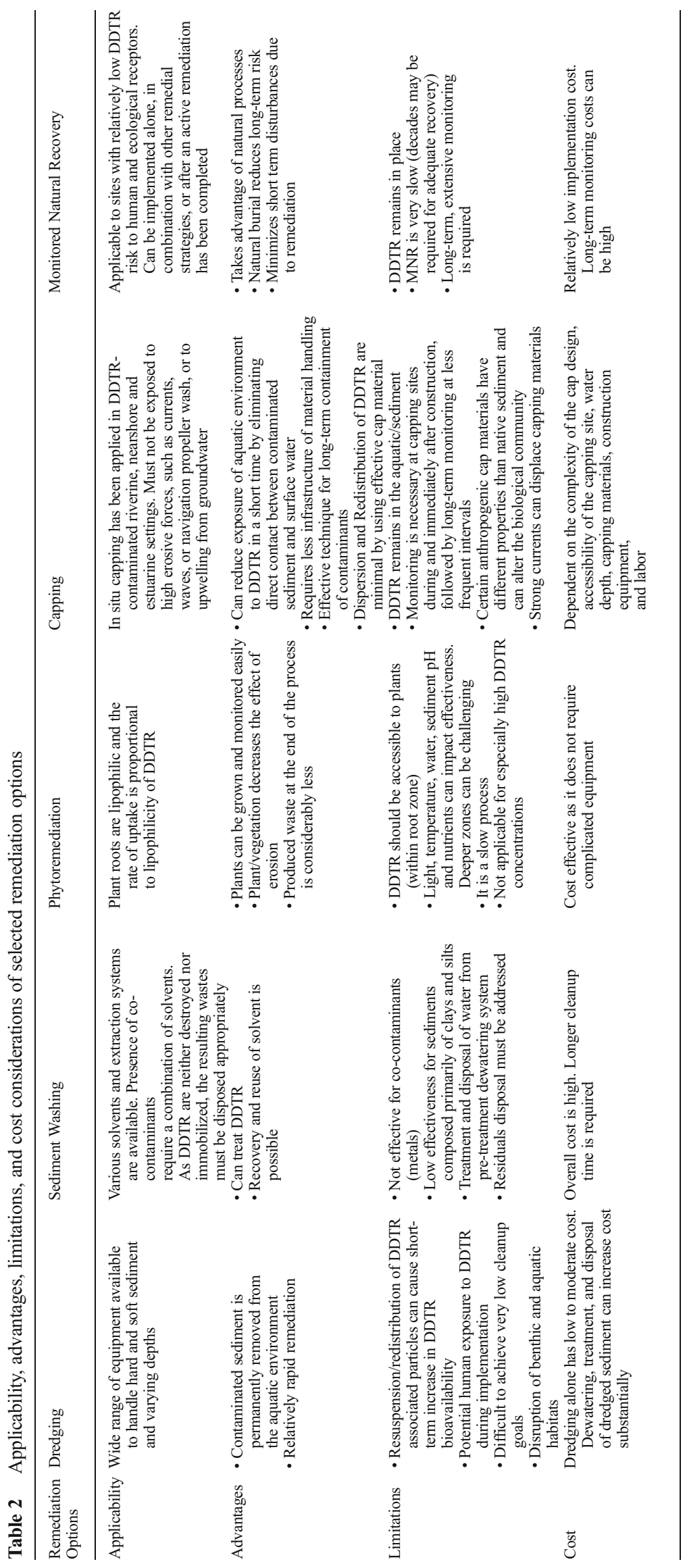


sediments were removed by a clam shell dredger between September 1996 and March 1997. Prior to dredging, the total concentrations of DDT and metabolites in the upper $10 \mathrm{~cm}$ of the sediment column ranged from 7 to $1318 \mathrm{mg} / \mathrm{kg}$, with an average concentration of $263 \mathrm{mg} / \mathrm{kg}$. Weston et al. [106] evaluated the performance of the remediation, in particular, focusing on DDTR in a wide variety of species. Dredging of contaminated sediment $\left(102,000\right.$ metric tons or $\left.82,000 \mathrm{~m}^{3}\right)$ was feasible because the canal is relatively small (460-m long, 60$\mathrm{m}$ wide, 3- to 12-m deep) and there was a rail line adjacent to the canal for transport of the contaminated dredged material. Excavated sediments were mixed with sodium silicate and Portland cement to thicken the material and improve handling properties and were then carried by rail to disposal sites in Arizona and Utah. Clean sand, as capping material for any residual contaminated sediment and to enhance the habitat value for demersal fishes, was spread on the bottom of the canal and under the structures. The amount of sand pumped into the canal was sufficient to cover the entire bottom to a depth of $30 \mathrm{~cm}$ if spread uniformly, although actual depth varied considerably. Despite the removal of 3 tons of DDTR (considering the average pesticide concentration in sediment), Weston et al. [106] reported that reduction of DDT concentrations in surficial sediments after remediation was incomplete. Though confirmation sampling immediately after dredging confirmed achievement of the cleanup goal of $0.59 \mathrm{mg} / \mathrm{kg}$ in the Lauritzen Channel, an investigation conducted a year later, in 1998 , found DDT concentrations as high as $30.1 \mathrm{mg} / \mathrm{kg}$ [72].

Sand is a generally inert material and is not effective for contaminant containment [39, 40]. Migration of DDTR is particularly frequent in sandy materials where the organic matter content is small. Schaanning et al. [87] measured the uptake of DDT by passive membrane samplers (SPMDs) at the Oslo harbor, Norway, and estimated fluxes of DDT through sand cap as $13.6 / \mathrm{pmol} / \mathrm{m}^{-2} /$ day. Because the secondary metabolites (DDE and DDD) are more soluble than DDT, they are more mobile and hence, are often transported via surface and groundwater flows into rivers and lake sediments. Dredging activities remobilized DDTR and increased pesticide body burdens in biota present in the canal during remedial actions. After completion of dredging, the canal bottom was quickly covered by a veneer of sediments that were as contaminated as the sediments present prior to dredging. Direct exposure of the biota to the redeposited surficial layer of contaminated sediments and indirect exposure via trophic transfer of DDTR led to pesticide body burdens that were similar or greater than body burdens before dredging.

The remedial action work at operable unit $2(\mathrm{OU}-2)$ at the Velsicol Chemical Superfund Site, St. Louis, Michigan, removed an estimated $490,000 \mathrm{~m}^{3}$ of DDT-contaminated sediments (an estimated 222 tons of DDT) from the Pine River. The total DDT concentrations in the sediment ranged from 1.3 to $32,600 \mathrm{mg} / \mathrm{kg}$. After the removal of contaminated sediment, confirmation sampling of the underlying glacial till showed remaining total DDT concentrations were less than the cleanup level of $5 \mathrm{mg} / \mathrm{kg}$ [89]. The Comprehensive Environmental Response, Compensation and Liability Act (CERCLA) requires that, at least every 5 years, a review of remedial actions be conducted to evaluate the implementation and performance of a remedy. The 5-year review found that the remediation performed at this site as a whole is not protective of human health and the environment [27] as DDT levels in fish did not decrease to safe risk-based target levels. It seems that recontamination of sediment can occur from other previously unknown areas of DDT contamination, thereby making the recovery/removal of contamination difficult. Dredging of sediment will remove known contamination but a significant time period may be required before potential ecological hazard is reduced, fish tissue concentrations decrease, and risk to human health can be reduced. A schematic diagram on the shifts in mode of occurrence of organic contaminants before, during and after dredging activities is shown in Fig. 2.

Removal of contaminated sediment by hydraulic dredging of the Big Sunflower River, Mississippi, resulted in a decrease in DDT concentration in fish tissue by more than $85 \%$, and most of the fish tested were below the $1.0 \mathrm{mg} / \mathrm{kg}$ limit [92]. Despite the results seen at the Big Sunflower River [71], dredging activities may cause adverse environmental threats if they are not well planned and implemented [73, 88, 100]. Dredging-induced sediment resuspension is a major environmental concern. Given no significant disturbance, buried DDT and other contaminants are generally sorbed by sediment, and can generally be regarded as separated from the overlying water. Activities such as dredging, shipping, and natural incidents, such as storms and tides, can remobilize DDT that was sorbed by sediment [100]. After comparing different dredging techniques, Wang et al. [105] suggested that a combination of mechanical and hydraulic dredging produces the least sediment resuspension.

Mathematical models were developed to estimate dredging costs, efficiency, and environmental effects [9, 48]. It has been reported that the cost of active contaminated sediment remediation, including environmental dredging, could be as high as US $\$ 1409 / \mathrm{m}^{3}$ [81] and the cost of disposal of dredged sediment via confined disposal facility varies from US $\$ 408$ to US\$658K/acre. Nadeau and Erickson [68] reported that the average dredging project cost (44 projects) is about US\$564/ $\mathrm{m}^{3}$.

\section{Sediment Washing}

Sediment washing is an ex situ technique in which DDTR and other contaminants sorbed onto fine sediment particles are 
separated from bulk solids in an aqueous-based system on the basis of particle size. The contaminants are removed from the sediment in one of two ways: (a) dissolving or suspending them in the wash solution or (b) concentrating them into a smaller volume of sediment through particle size separation, gravity separation, and attrition scrubbing [16]. Washing of contaminated sediment is an alternative remediation option where the solubilities of DDTR are greatly enhanced using a surfactant at a concentration above its critical micelle concentration $(\mathrm{cmc})$. The desirable characteristics of a surfactant in sediment washing are the following: biodegradable and soluble at ambient temperature at the time of sediment processing, low toxicity, low sorption to sediment, low surface tension, and low cmc level. Ghazali et al. [42] reported that a mixture of Brij 35, a nonionic surfactant, and sodium dodecyl benzene sulfonate, an anionic surfactant, was more effective than individual surfactants in removing DDTR. Wash-off liquids containing DDTR are treated (dechlorinated) in the next step using different methods, such as degradation using zero-valent iron under anaerobic conditions [86], reducing agents (cysteine or sodium sulfide), or photodechlorination reaction [19]. Nash et al. [70] found that increase in $\mathrm{pH}$ by addition of lime enhanced conversion of DDT to DDE at the expense of DDD. Sediment washing has a fast processing time, is carried out under controlled conditions without the risk of mobilizing the contaminants into the surrounding environment, and can provide a cost-effective ex situ treatment alternative to stabilization and land-filling. A few limitations of this remediation option are as follows: (a) not always effective on all sediment types and works better on certain grain sizes than others, (b) high levels of organic matter inhibit desorption, (c) aqueous stream will require treatment prior to disposal/demobilization, and (d) complex mixtures of contaminants may require multiple wash regime (chemical extraction, chemical oxidation/reduction, advanced separation techniques, and others).

The cost of sediment washing technologies can range from US $\$ 40$ to US\$200 per ton $[32,59]$. This range reflects variables such as amount of DDTR and other co-contaminant, treatment goals, volume of sediment, and site conditions (accessibility, geographical location, physical conditions, availability of utilities, and others).

\section{Phytoremediation}

Phytoremediation is an environmentally friendly, potentially effective, and inexpensive technology using plants to decontaminate sediments or surface waters from organic contaminants [62]. Phytoremediation as a sediment management option has been used in shallow water, tidal marshes, flood control areas, and dredged sediment landfill sites $[8,77,83]$. One of the remediation steps is rhizoremediation (the degradation of contaminants in the rhizosphere), which is especially suitable for DDTR. It utilizes (a) the flow of root exudates that alter the composition of the rhizosphere microbial community, supporting the growth of pollutant-degrading microorganisms; (b) the release of oxygen promoting degradation of contaminants; and (c) enzymes occurring within root exudates (laccases, dehalogenases, nitroreductases, nitrilases, cytochrome 450 , or peroxidases) involved in the degradation. The root exudates not only support the growth of degrading microorganisms, but also change the structure and function of microbial community (cometabolism) in the rhizosphere. Rhizosphere microorganisms promote plant growth by producing growth-enhancing hormones, increasing nutrient availability and degrading pollutants. Rhizosphere microorganisms can degrade organic contaminants to volatile compounds or humic substances.
Fig. 2 Schematic view of the occurrence of DDTR in sediment before, during, and after dredging activities. $O M P$ organic micropollutant, $P O M$ particulate organic matter, DOM dissolved organic matter

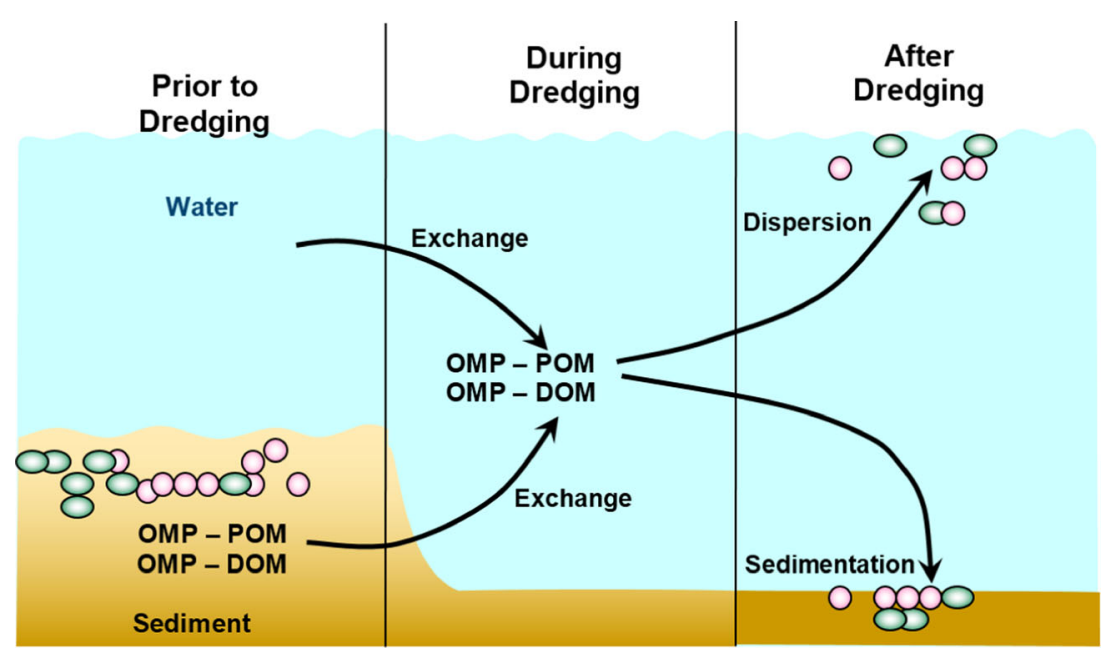


The role of plants and root exudates in DDTR biodegradation has yet to be studied extensively, but Garrison et al. [38] have reported that plants transformed DDT to DDD. The plant can bind up to $22 \%$ of the ${ }^{14} \mathrm{C}$-DDTR generated. The dechlorination activity did not require either surface microbial flora or living plant tissue, and was assumed to be catalyzed nonenzymatically by a biological reductant. Phenolic root exudates [35] and terpenes [52] may also foster the activity of rhizosphere bacteria that degrade DDTR by inducing enzymes or providing co-metabolic growth substrates, although the available concentrations of such exudates may be low outside localized pockets. Lunney et al. [65] evaluated preferential translocation or transformation of DDTR compounds within vascular plant varieties. They reported that the Cucurbita pepo species effectively remediated DDTR through their high transpiration volume, large above-ground biomass, and composition of root exudates to translocate hydrophobic chemicals across the root and through the shoot via an aqueous transpiration stream.

Phytoremediation of DDTR may not be feasible for highly contaminated sediment, since high concentrations of DDTR are toxic to plants, but it can be used as an appropriate polishing technology for residual contamination in the sediment and water column. The Connecticut Agricultural Experimental Station's preliminary data have shown that a narrow range of plant species (certain cucurbitas) can effectively accumulate significant amounts of highly weathered pesticide residues such as DDE and chlordane [107].

Phytoremediation cost analysis was developed using Remedial Action Cost Engineering and Requirements (RACER) software. The cost of phytoremediation ranged from US\$2/ square foot to US\$7/square foot depending on the area of contamination and site complexity [102].

\section{In Situ Cap}

Capping involves covering DDTR-contaminated sediments with a multi-layered cap which includes a layer of chemically or biologically reactive material and/or a stabilizing layer of granular material overlying the reactive layer. The reactive materials (or amendments) are used to improve the overall effectiveness of the cap to sequester DDTR in the sediments from migrating into the overlying aquatic environment. An appropriate material that contains reactive ingredients would provide sequestration of DDTR by designing and achieving the following risk reduction objectives: (a) physical isolation of the contaminated sediment sufficient to reduce exposure due to direct contact and to reduce the ability of burrowing organisms to move contaminants to the surface, (b) stabilization of contaminated sediment and erosion protection of sediment and cap, sufficient to reduce re-suspension and transport to other sites, and (c) chemical isolation of contaminated sediment sufficient to reduce exposure from dissolved and colloidal-bound contaminants transported into the water column [25]. A cap affects aquatic organisms significantly less than dredging does because it generates less resuspension and residual contamination [53]. Capping does not require upland sediment processing, transportation, and disposal and associated equipment needed for dredging, which is a significant advantage that reduces environmental impacts of capping (such as greenhouse gases and energy requirements).

Some integral characteristics of the cap material, such as hydraulic conductivity, sorption parameters, and organic content, determine its efficacy to contain DDTR. The performance of a cap material to contain DDTR is dependent on inherent physical-chemical characteristics of cap material and co-contaminants and their interactions under the sitespecific environmental condition. It should be noted that application of an inert cap material with high permeability (such as sand) will allow the percolation and mobilization of colloidal and organic particles from the sediment layers. These particulates will transfer from the sediment layer to the cap layer and may be released to the water column unless the cap material binds the DDTR.

A summary of the sorption characteristics of various materials that interact with DDT are listed in Table 3. The summarized parameters include partition coefficient, $\mathrm{Kd}$ (ratio of a DDT sorbed concentration $(\mathrm{mg} / \mathrm{kg})$ to the dissolved concentration $(\mathrm{mg} / \mathrm{L})$ as expressed by $\mathrm{L} / \mathrm{kg})$, DDT half-lives, and removal percentages. The Kd values on materials with high organic content (i.e., sediment, humic material, pine bark, and wood charcoal) and low organic content materials (i.e., sandy soils) are presented in the table. High organic content materials have higher Kd values for DDT and DDTR than sand or similar low carbon materials. For example, the $\mathrm{Kd}_{\mathrm{DDT}}$ for pine bark and wood charcoal is 220.5 [56] and $843.1 \mathrm{~L} / \mathrm{kg}$ [11], respectively. However, the $\mathrm{Kd}_{\mathrm{DDT}}$ of Montcalm Sandy Loam, though it contains relatively high $(0.99 \%)$ carbon, is only $0.13 \mathrm{~L} / \mathrm{kg}$ [93]. A potential application of biochar, a stabilized, carbon-rich by-product derived from pyrolysis of biomass, has been discussed by Yavari et al. [111].

The hydraulic conductivity of the cap material plays a crucial role in the fate and transport of DDT. Sand, a porous material, has a typical hydraulic conductivity between 14.6 and $29.7 \mathrm{~cm} / \mathrm{h}$, whereas the hydraulic conductivity of silty clay materials range between 0.02 and $0.26 \mathrm{~cm} / \mathrm{h}$ [60]. DDT can readily sorb on lighter organic colloids or particulates. This particulate- or colloid-associated DDT could easily permeate through porous sand or silt cap and become entrained in the water due to the fluctuating water depth. Therefore, a cap material amended with organic material with a low hydraulic conductivity would be a better choice as a barrier for DDTR. Schematic diagrams in Fig. 3 depict the transfer of DDTR from the sediment surfaces through the permeable sand material during water fluctuating conditions.

Sorption of DDTR on sediment and/or cap material is probably the most important mode of interaction between sediment 


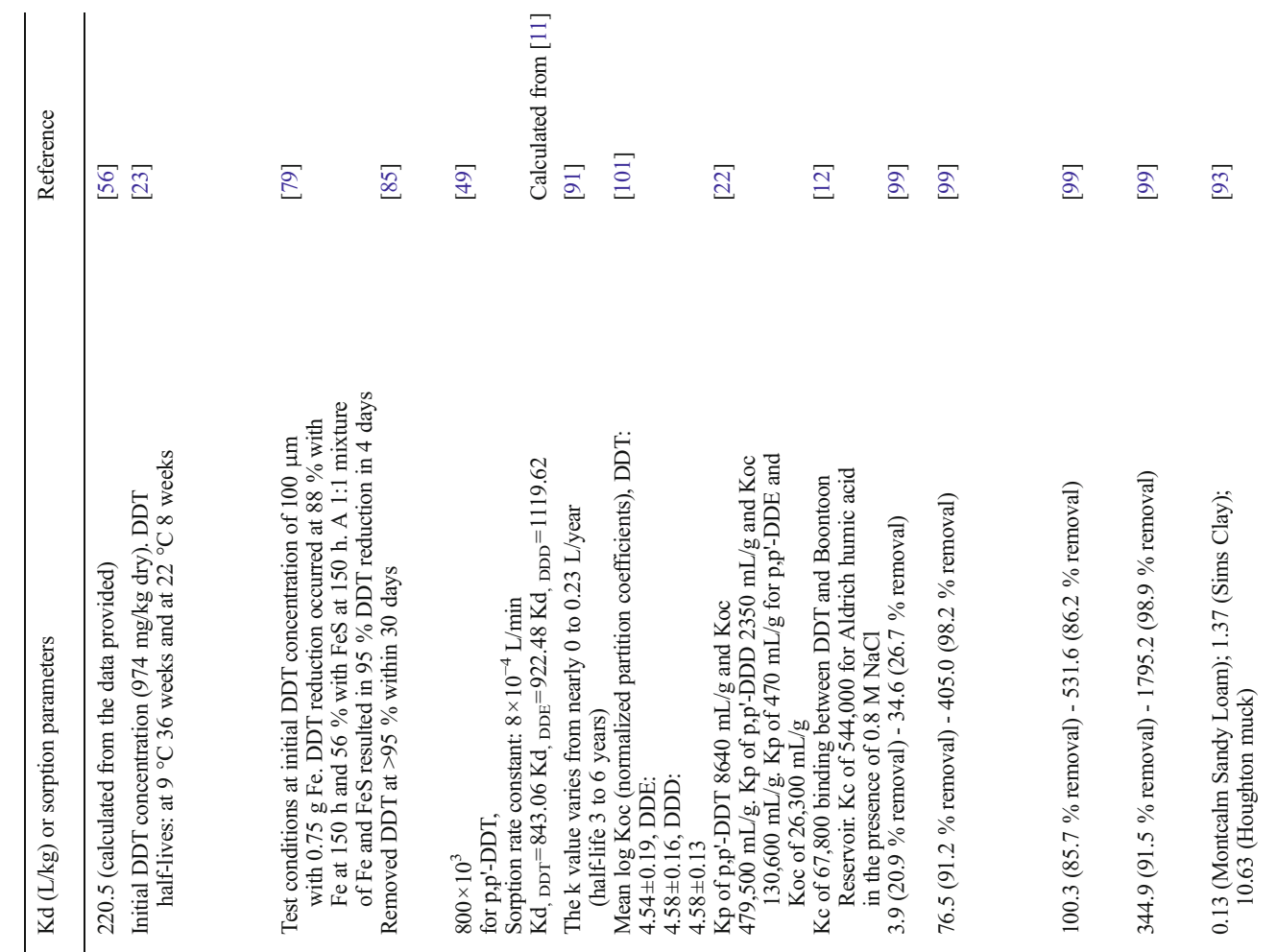


Fig. 3 DDTR migration potential through in-place sediment cap

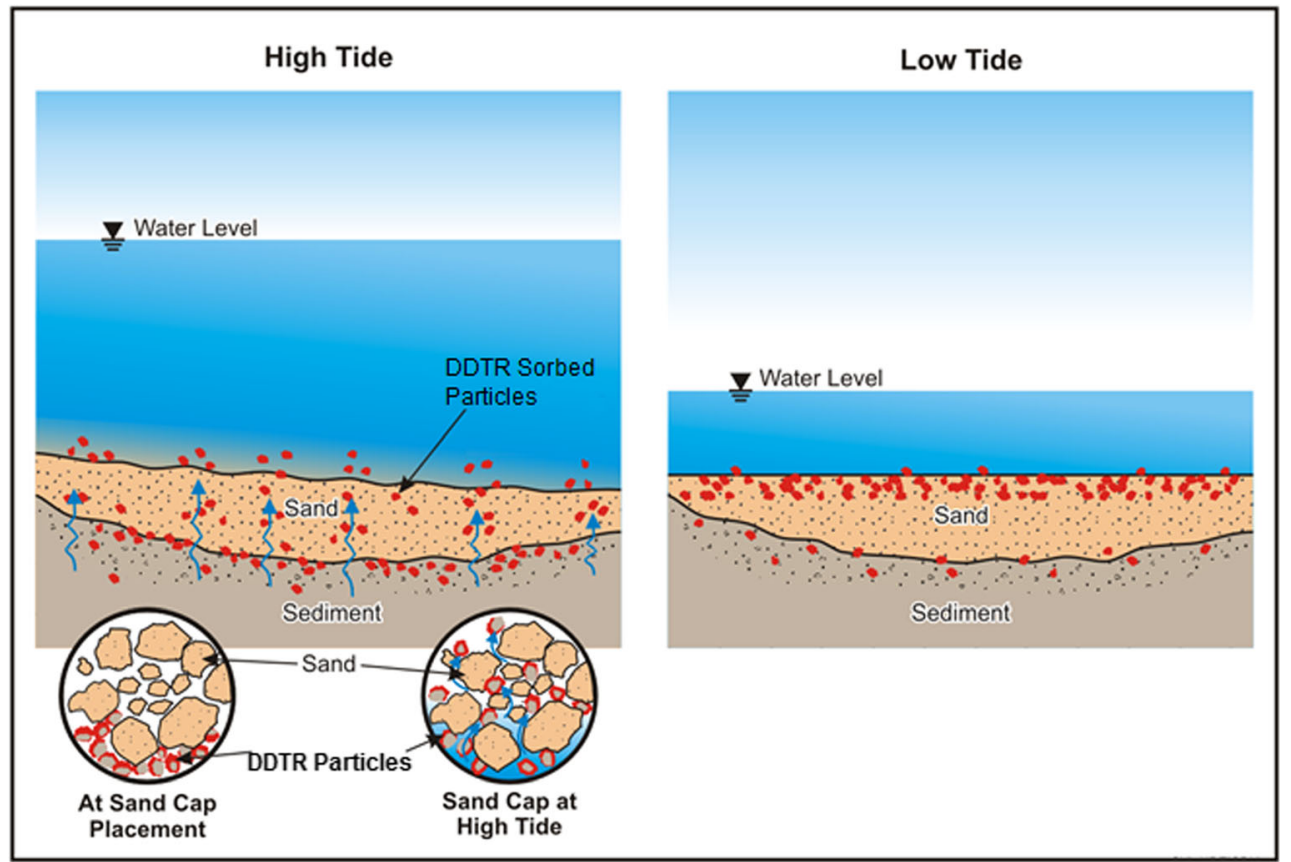

and pesticides, and controls the pore water concentration of the latter in the sediment-water environment. Sorption processes may vary from complete reversibility to total irreversibility [41]. The extent of sorption depends on the properties of sediment and the DDTR, which include size, shape, configuration, molecular structure, chemical functions, solubility, polarity, and polarizability and charge distribution of interacting species. Sorption may be purely physical, as with van der Waals forces, or chemical in nature, as with electrostatic interactions. Chemical reactions between DDT or its metabolites often lead to the formation of stable chemical linkages, resulting in an increase in the persistence of the residue in sediment, while causing it to lose its chemical identity [20]. From a toxicological perspective, binding of DDTR to effective cap material leads to the following: (a) a decrease of material available to interact with biota; (b) a reduction in the toxicity of the compound; and (c) immobilization of the compound, thereby reducing its leaching and transport properties [20]. The nature of the binding forces involved and the types of mechanisms operating in the sorption processes of DDTR onto the cap material/amendments include ionic, hydrogen and covalent bonding, charge-transfer or electron donor-acceptor mechanisms, van der Waal forces, ligand exchange, and hydrophobic bonding or partitioning. Not all mechanisms occur simultaneously; however, two or more can occur simultaneously depending on the nature of the functional group of amendments and the acidity of the system. It should also be noted that bound residue formation is not equivalent to the strong sorption of DDTR. The processes that are reversible by available extraction techniques do not lead to bound residue formation. Increased contact time between sediment and DDT or aging leads to the formation of unextractable residues. With longer residence times in the sediment, bound DDTR residues tend to lose their biodegradability and become even more resistant to degradation and extraction. Aging is thought to be the result of either a redistribution of the DDT from weaker to stronger sorption sites, slow chemisorption/sequestration, or covalent bond formation between the compounds and sediment organic matter [41]. Chemisorption/ sequestration possibly involves a continual strengthening of sorption bonds, characterized by an initial rapid sorption followed by a slow but sustained rate of sorption [110]. Covalent interaction between DDTR and sediment humic or cap material leads to the formation of very stable bonds.

Carbonaceous materials generally bind hydrophobic DDTR [99]. A highly porous structure of a hydrophobic solid substrate even provides a larger surface area and is very efficient in removing different varieties of pesticides [17, 39]. The use of by-products or residues of agricultural materials, such as biochar, coconut shell/fiber, peat moss, and others are environmentally sustainable and can be effective for removal of DDTR and other co-contaminants. Granular activated carbon (GAC), however, is more expensive compared to the natural carbonaceous material (such as natural sorbents or by-products from the plant lignocellulosic material) that can be readily available near a contaminated sediment site. It is important to ensure that mobility and toxicity to biota must be reduced as a result of capping. Kupryianchyk [58] studied the ecological 
effects of the presence of activated carbon in sediments, and reported that the application level of 2 to $4 \%$ activated carbon negatively affected survival of the amphipods Gammarus pulex. Millward et al. [66] also reported that the use of activated carbon resulted in decreased polychaete (Neanthes arenaceodentata) wet weight of approximately $50 \%$ after 28 days. These researchers indicated that presence of commercially available activated carbon interfered with the nutrient uptake by the native biota. In contrast, natural carbon resource available near a contaminated sediment site can be attractive as it might be cost effective and the habitats and biota (flora and fauna) might be well acclimated to this material. Tetra Tech [99] reported sequestration of DDT on black carbon present at the Abraham's Creek, Quantico, Virginia. Clay materials that are present in the natural black carbon possess layered mineral structure and are host materials for sorbates and counter ions. Smectite clays have very large specific surface areas and between layers they can bind organic molecules. The sorption of 4,4'-DDT to clays was reported to be an electrostatic attraction between aromatic hydrogen atoms of 4,4'-DDT and negatively charged surfaces of the clays [10]. Parween et al. [76] indicated that black carbon has rigid three-dimensional structures and is often less polar than humic substances. In addition, aging of the black carbon can cause changes in surface properties with increased elemental oxygen, carboxylic, and phenolic functional groups; disappearance of surface positive charges; and evolution of surface negative charges [18]. The availability of these functional groups makes black carbon more attractive in sequestering DDTR.

ITRC [53] reported that the cost of capping is substantially less than dredging options. Cost to cap is typically $30 \%$ of the cost to dredge and dispose [33, 74]. Costs for sediment capping can vary widely and depend on a number of site-specific parameters. The primary cost items can be divided into three categories including pre-implementation costs (nature and extent of DDT contamination, sediment characterization, water quality, and hydrologic survey); fixed costs (site preparation, mobilization/demobilization, equipment for cap placement, cap material, and waste disposal); and variable costs (utilities, sampling and analyses, labor). The cost of cap material varies based on the type, purity, size, delivery, and other conditions. The cost of representative cap materials from various suppliers are shown in Fig. 4.

\section{Natural Attenuation}

Natural attenuation of DDTR associated with sediments has been reported to occur through physical-chemical (hydrolysis, volatilization, and photochemical) and biological (aerobic and anaerobic biodegradation) processes [95]. Quensen et al. [80] found that naturally occurring organisms in sediments play an important role in breaking down the chlorinated compounds. These researchers conducted DDT degradation experiments using marine sediments collected from a Superfund site off the coast of southern California on the Palos Verdes Shelf, and found that in 32 weeks, microbes transformed some of the DDE to 1-chloro-2,2-bis(p-chlorophenyl)ethylene (DDMU), under both methanogenic and sufidogenic conditions. DDMU, which has one less chlorine atom, does not bioaccumulate as readily as its parent, and it is also subject to reductive dechlorination. The most rapid dechlorination rate observed in the absence of sulfate and at room temperature corresponds to a half-life of 17 weeks $[80,82]$. In the presence of sulfate and at room temperature, the half-life observed was approximately 3 years [80]. Based on the two decades of data collected by the Los Angeles County Sanitation District and the US Geological Survey, Quensen et al. [80] estimated that the DDE in the Palos Verdes sediment has a half-life of approximately a decade.

Degradation of DDTR in sediment is affected by moisture, $\mathrm{pH}$, temperature, oxygen levels, bioavailability (sorption, bacterial dispersion, concentration, and solubility), and bacterial nutrient requirements. The degradation of $p, p^{\prime}-D D T$ due to various organisms (i.e., bacteria, fungi) is known to occur naturally in the environment by two main routes: oxidative degradation under aerobic conditions and reductive degradation under anaerobic conditions [34]. Under aerobic conditions, $\mathrm{p}, \mathrm{p}^{\prime}$-DDT is generally converted to $\mathrm{p}, \mathrm{p}^{\prime}$-DDE, usually by dehydrochlorination by bacteria [2]. Aerobic degradation also tends to promote ring cleavage and occurs more quickly in warm and moist conditions. Although a few studies have shown that DDE can be further degraded under anaerobic and aerobic conditions $[47,80]$, DDE is generally recalcitrant to microbial degradation and under most conditions is seen as a dead-end metabolite. Enhanced p,p'-DDT degradation under reducing conditions was reported when a carbon source is available [2]. The degradation process is due mainly to the actions of facultative anaerobic microorganisms present in the native sediment and also to chemical reactions with the minerals present in the sediment. Anaerobic degradation generally converts $\mathrm{p}, \mathrm{p}^{\prime}$-DDT to $\mathrm{p}, \mathrm{p}$-DDD by reductive dechlorination (hydrogenolysis), where a single chlorine atom is substituted by a hydrogen atom. Although p,p'-DDD alone was a regulated pesticide, it can undergo further degradation to less harmful metabolites, such as DDMU and 1-chloro2,2bis(p-chlorophenyl)ethane (DDMS) [2].

Clay minerals are often abundant in sediments, and due to their small particle size, large surface area, and often large cationic exchange capacity (CEC), clay minerals play a key role in many biogeochemical processes. Many varieties of clay minerals, such as smectite, may contain substantial amounts of $\mathrm{Fe}(\mathrm{III})$ in their structure $[14,15]$. Fialips et al. [34] have shown that bacterially reduced Fe-bearing clay minerals can substantially contribute to the reductive 
Fig. 4 Cost of cap materials

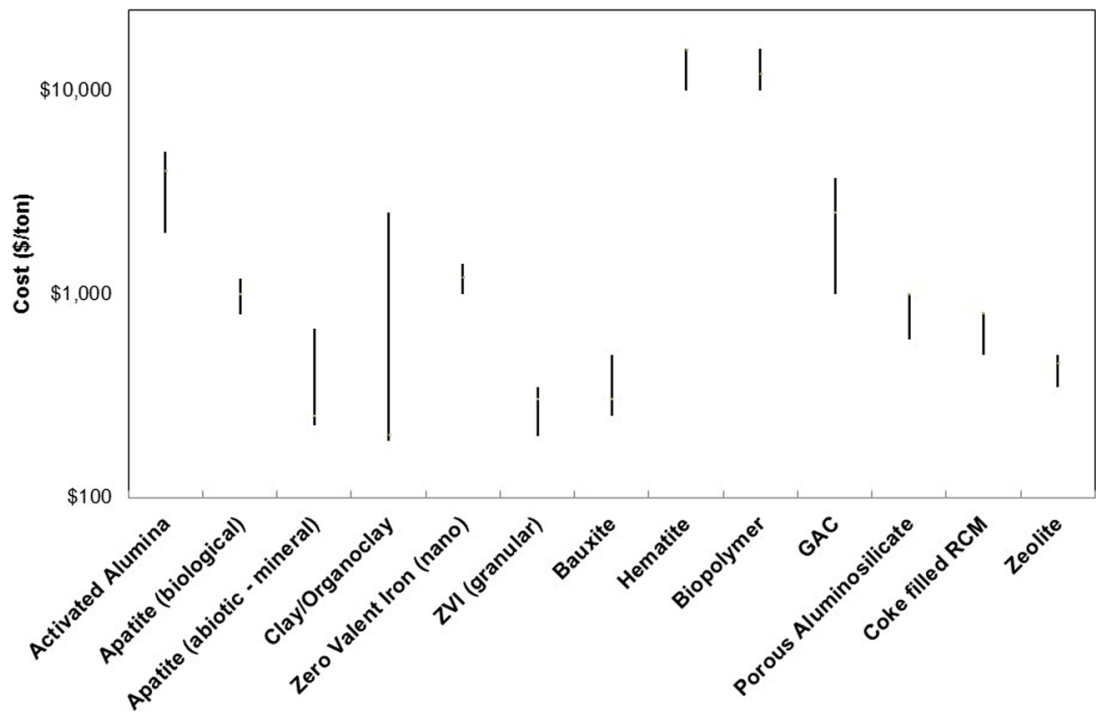

dechlorination of DDT to DDD. Clay minerals present in sediment play a crucial role in the natural attenuation of DDT under anoxic conditions in sediment-water system. The binding of DDT to the natural organic matter present in the sediment increases the availability of p,p'-DDT to the clay surface, thereby facilitating its reductive degradation.

In general, natural attenuation can treat the DDTcontaminated sediment, but it can take long timeframes. Addition of suitable co-metabolites and acclimatized microorganisms to DDTR-contaminated sediment and alteration of sediment-water micro-environment by manipulating soil $\mathrm{pH}$, moisture content, and other chemical conditions may result in degradation of DDTR associated with sediments at rates faster than the natural attenuation rate [70, 95]. Singh et al. [95] compared reduction in DDTR through the natural attenuation process (incidental physicochemical and biological process such as photolysis, hydrolysis, volatilization and biodegradation); enhanced biodegradation (aerobic and anaerobic degradation with added acclimatized microorganisms and cometabolites); and nanoscale zero valent iron (NZVI) addition. They reported that the reduction in sorbed DDTR concentration was 10 $15 \%$ over a period of 105 days in both aerobic and anaerobic conditions. The extent of reduction in sorbed DDTR concentration during natural attenuation experiments under aerobic conditions was $25-30 \%$ over a period of 150 days, and reduction under anaerobic conditions was $15-20 \%$ over a period of 90 days. The DDTR concentration was reduced by $40 \%$ within $28 \mathrm{~h}$ during the experiments involving NZVI addition. The rate of DDT degradation was zero order and involved attachment of NZVI particles to DDTR sorbed on sediment, leading to direct electron transfer from NZVI particles to DDTR resulting in reductive dechlorination of DDTR.
The two primary advantages of natural attenuation are its relatively low implementation cost and its non-invasive nature that does not need construction/infrastructure. The costs associated with characterization and monitoring to evaluate natural recovery can be extensive. The key limitations of natural attenuation may be the potential risk of re-exposure or dispersion of buried DDT if the sediment bed is disturbed by strong natural or synthetic forces and uncertainties in predicting various situations, like, future sedimentation rates in dynamic environments, rate of contaminant flux through stable sediment, or rate of natural recovery. Contaminated systems in natural attenuation should be regularly monitored to ensure environmental safety.

The primary cost associated with implementing natural attenuation are site investigation and monitoring. However, site characterization is essential irrespective of the remedial measure. In case of natural attenuation, results from the initial characterization can be part of the database to be developed from site monitoring.

\section{Summary}

Sediments are repositories for physical and biological debris, and sinks for DDTR. The direct transfer of chemicals from sediments to organisms is a major route of exposure for many species. The sediment, overlying water column, fate, and transport of DDTR must be considered when determining DDTR release from sediment and the appropriate remediation option. DDTR and other cocontaminants are not necessarily fixed permanently in the sediments. Changes in geochemical and physical parameters (e.g., ORP or anoxic environment, seepage, water table fluctuation) may cause mobilization of these species. 
Furthermore, remobilization processes can include the diffusion of DDTR into the water body, due to concentration gradients, oxidation of anoxic sediments by bioturbation, or resuspension caused by flooding. DDTR can be transformed or partially degraded in sediments under appropriate environmental conditions. Unfortunately, the degradation products are as toxic and persistent as the original pesticides or chlorinated organics. Five remediation technologies have been applied to remediate the DDTcontaminated sediment sites are dredging, sediment washing, phytoremediation, in situ capping, and natural attenuation. The selection of appropriate remediation option depends on site specific conditions. However, several of the natural and innovative reactive cap materials show promises in remediating the DDTR.

\section{Compliance with Ethical Standards}

Conflict of Interest On behalf of all authors, the corresponding author states that there is no conflict of interest.

\section{References}

1. Adams K. Status of the Benthic macroinvertebrate community in the Wenatchee River, 2010. Olympia: Washington State Department of Ecology; 2012. Publication No. 12-03-016.

2. Aislabie JM, Richards NK, Boul HL. Microbial degradation of DDT and its residues: a review. N Z J Agric Res. 1997;40:269-82.

3. Augustijn-Beckers PWM, Hornsby AG, Wauchope RD. SCS/ ARS/CES pesticide properties database for environmental decision-making II, additional compounds. Rev Environ Contam Toxicol. 1994;137:1-82.

4. ATSDR. Toxicological profile for chlorinated dibenzo-p-dioxins. U.S. Department of Health and Human Services, Atlanta. Agency for Toxic Substances and Disease Registry; 1994. 721 pp.

5. ATSDR. Toxicological profile for DDT, DDE and DDD. U.S. Department of Health and Human Services, Atlanta. Agency for Toxic Substances and Disease Registry; 2002. 403 pp.

6. Barbosa MC, Soares de Almeida MS. Dredging and disposal of fine sediments in the state of Rio de Janeiro, Brazil. J Hazard Mater. 2001;85:15-38.

7. Battelle. Site 102-Abraham's Creek supplemental remedial investigation report. Washington, D.C.: U.S. Navy, Naval Facilities; 2013.

8. Bert V, Seuntjens P, Dejonghe W, Lacherez S, Thuy HT, Vandecasteele B. Phytoremediation as a management option for contaminated sediments in tidal marshes, flood control areas and dredged sediment landfill sites. Environ Sci Pollut Res Int. 2009;16(7):745-64.

9. Blazquez CA, Adams TM, Keillor P. Optimization of mechanical dredging operations for sediment remediation. J Waterw Port Coast Ocean Eng. 2001;127:299-307.

10. Boul HL. DDT residues in the environment — a review with a New Zealand perspective. N Z J Agric Res. 1995;38(2):257-77.

11. Brás IP, Santos L, Alves A. Organochlorine pesticides removal by Pinus bark sorption. Environ Sci Technol. 1999;33(4):631-4.
12. Carter CW, Suffet IH. Binding of DDT to dissolved humic materials. Environ Sci Technol. 1982;16(11):735-40.

13. CCME. Canadian sediment quality guidelines for the protection of aquatic life: DDT, DDE, and DDD. Winnipeg: Canadian Council of Ministers of the Environment; 1999.

14. Chattopadhyay S, Puls RW. Adsorption of bacteriophages on clay minerals. Environ Sci Technol. 1999;33(20):3609-14.

15. Chattopadhyay D, Chattopadhyay S, Lyon WG, Wilson JT. Effect of surfactants on the survival and sorption of viruses. Environ Sci Technol. 2002;36(19):4017-24.

16. Chattopadhyay S. Evaluation of ex-situ treatment of contaminated sediments using BioGenesis ${ }^{\mathrm{SM}}$ sediment washing technology: remediation technology demonstration project profiles on Porto Marghera in Venice Lagoon and at the Harrison Reach of the lower Passaic River. Sixth International Conference Proceedings on Remediation of Contaminated Sediments. New Orleans, Louisiana; 2011.

17. Chattopadhyay S. Materials and methods for environmental contaminant remediation. US Patent Publication 2013/0306555 A1. 2013.

18. Cheng CH, Lehmann J, Engelhard MH. Natural oxidation of black carbon in soils: changes in molecular form and surface charge along a climosequence. Geochim Cosmochim Acta. 2008;72(6): 1598-610.

19. Chu W. Photodechlorination mechanism of DDT in a UV/ surfactant system. Environ Sci Technol. 1999;33:421-5.

20. Dec J, Bollag J. Determination of covalent and non-covalent binding interactions between xenobiotic chemicals and soil. Soil Sci. 1997;162:858-74.

21. Department of Interior. Guidelines for interpretation of the biological effects of selected constituents in biota, water, and sediment. National Irrigation Water Quality Program Information Report No. 3. 1998.

22. Ding JW, Wu SC. Partition coefficients of organochlorine pesticides on soil and on the dissolved organic matter in water. Chemosphere. 1995;30:2259-66.

23. Eggen T, Majcherczyk A. Effects of zero-valent iron ( $\mathrm{Fe} 0)$ and temperature on the transformation of DDT and its metabolites in lake sediment. Chemosphere. 2006;62(7):1116-25.

24. EPA. Environmental fate and effects division, pesticide environmental fate one line summary: DDT ( $\left.p, \mathrm{p}^{\prime}\right)$. Washington, DC; 1989.

25. EPA. Guidance for in-situ subaqueous capping of contaminated sediment. EPA 905/B-96/004. Chicago: Great Lakes National Program Office; 1998.

26. EPA. Bioaccumulation testing and interpretation for the purpose of sediment quality assessment. status and needs. EPA 823-R-00001. Office of Water and Office of Solid Waste; 2000.

27. EPA. Third five-year review report for velsicol chemical corporation site, St. Louis Gratiot County, Michigan. EPA Region 5, Chicago, Illinois; 2007.

28. EPA. Reference guide to non-combustion technologies for remediation of persistent organic pollutants in soil. EPA 542-R-09-007. 2010.

29. EPA. Proposed plan Olin McIntosh Operable Unit 2. Washington County, Alabama; 2013.

30. EPA. Update on cleanup activities at Velsicol Site: Velsicol Chemical Corp. Superfund Site: St. Louis, Michigan. EPA Region 5, Chicago, Illinois; 2015.

31. EPA. Update on cleanup activities at Velsicol Site. St. Louis: Velsicol Chemical Corp. Superfund Site; 2015.

32. Estes TJ, Magar VS, Averett DE, Soler ND, Myers TE, Glisch EJ, et al. Mass balance, beneficial use products, and cost comparisons of four sediment treatment technologies near commercialization. Vicksburg, Mississippi: U.S. Army Corps of Engineers, Engineer Research and Development Center; 2011. Report ERDC/EL TR-11-1. 
33. Evison L, Grasso N, Stansbury J. Dollars and sense in risk management decision making. Proceedings on USACE/USEPA/ SMWG joint sediment conference on addressing uncertainty and managing risk at contaminated sediment sites. St. Louis, Missouri; 2004.

34. Fialips RI, Cooper NGA, Jones DM, White ML, Gray ND. Reductive degradation of $\mathrm{p}, \mathrm{p}^{\prime}-\mathrm{DDT}$ by $\mathrm{Fe}(\mathrm{II})$ in nontronite NAu-2. Clay Clay Miner. 2010;58(6):821-36.

35. Fletcher JS, Hegde RS. Release of phenols by perennial plant roots and their potential importance in bioremediation. Chemosphere. 1995;31:3009-16.

36. Foght J, April T, Biggar K, Aislabied J. Bioremediation of DDTcontaminated soils: a review. Bioremediat J. 2001;5(3):225-46.

37. Frische $\mathrm{K}$. Investigations on the environmental fate and contamination potential of DDT-residues in river sediment and its implication for DDA pollution of corresponding surface waters. Doctoral dissertation. Berlin, Germany: der RheinischWestfälischen Technischen Hochschule Aachen (RWTH Aachen University); 2010.

38. Garrison AW, Nzengung VA, Avants JK, Ellington JJ, Jones WJ, Rennels D, et al. Phytodegradation of $\mathrm{p}, \mathrm{p}^{\prime}-\mathrm{DDT}$ and the enantiomers of o, p'DDT. Environ Sci Technol. 2000;34:1663-70.

39. Gavaskar AR, Chattopadhyay S. Treatment of environmental pollutants with mineral ores. US Patent 7,396,470 B2. 2008.

40. Gavaskar AR, Chattopadhyay S, Hackworth M, Lal V, Sugiyama B, Randall P. A reactive cap for contaminated sediments at the Navy's Dodge Pond site. Proceedings in Environmental Technology Technical Symposium \& Workshop, Washington, DC; 2005.

41. Gevao B, Semple KT, Jones KC. Bound pesticide residues in soils: a review. Environ Pollut. 2000;108:3-14.

42. Ghazali M, McBean E, Shen H, Anderson W, Dastous P. Remediation of DDT-contaminated soil using optimized mixtures of surfactants and a mixing system. Remediation. 2010; 119-131.

43. Gilbane Federal. First five-year review report for Palos Verdes Shelf. Los Angeles County, California. Region 9 Superfund Division, Federal Facilities and Site Cleanup Branch. 2014.

44. Gillis CA, Bonnevie NL, Su SH, Ducey JG, Huntley SL, Wenning RJ. DDT, DDD, and DDE contamination of sediment in the Newark Bay estuary, New Jersey. Arch Environ Contam Toxicol. 1995;28(1):85-92.

45. Gustavson KE, Burton GA, Francingues NR, Reible DD, Vorheeees DJ, Wolfe JR. Evaluating the effectiveness of contaminated-sediment dredging. Environ Sci Technol. 2008;42(14):5042-7504.

46. Hartwell SI. Distribution of DDT and other persistent organic contaminants in canyons and on the continental shelf off the central California coast. Mar Environ Res. 2008;65:199-217.

47. Hay AG, Focht DD. Cometabolism of 1,1-dichloro-2, 2bis (4chlorophenyl) ethylene by Pseudomonas acidovorans M3GY grown on biphenyl. Appl Environ Microbiol. 1998;64:2141-6.

48. Hayes DF, Crockett TR, Ward TJ, Averett D. Sediment resuspension during cutterhead dredging operations. J Waterw Port Coast Ocean Eng. 2000;126:153-61.

49. Headley JV, Gandrass J, Kuballa J, Peru KM, Gong Y. Rates of sorption and partitioning of contaminants in River Biofilm. Environ Sci Technol. 1998;32(24):3968-73.

50. Hendriks AJ, Ma WC, Brouns JJ, de Ruiter-Dijkman EM, Gast R. Modelling and monitoring organochlorine and heavy metal accumulation in soils, earthworms, and shrews in Rhine-delta floodplains. Arch Environ Contam Toxicol. 1998;29:115-27.

51. Hermanson MH, Moss DJ, Monosmith CL, Keeler GJ. Spatial and temporal trends of gas and particle phase atmospheric DDT and metabolites in Michigan: evidence of long-term persistence and atmospheric emission in a high-DDT-use fruit orchard. J Geophys Res. 2011;112(D04301):1-10.
52. Hernandez BS, Koh SC, Chial M, Focht DD. Terpene-utilizing isolates and their relevance to enhanced biotransformation of polychlorinated biphenyls in soil. Biodegradation. 1997;8:153-8.

53. ITRC. Contaminated sediments remediation remedy selection for contaminated sediments. Contaminated Sediments Team. Washington, DC: The Interstate Technology and Regulatory Council; 2014

54. Johnson WW, Finley MT. Handbook of acute toxicity of chemicals to fish and aquatic invertebrates. Resource publication 137. Washington, DC: U.S. Department of Interior, Fish and Wildlife Service; 1980.

55. Kantachote D, Naidu R, Williams B, McClure N, Megharaj M. Bioremediation of DDT-contaminated soil: enhancement by seaweed addition. J Chem Technol Biotechnol. 2004;79(6):632-8.

56. Keerthinarayana S, Vijayashankar YN, Shivalingaiah B, Visweswariah K. Sorption mechanism of DDT from aqueous phase. J Environ Sci Health B. 1990;25(4):493-509.

57. Korte N. A guide for the technical evaluation of environmental data. Lancaster: Technomic Publishing Company, Inc.; 1999.

58. Kupryianchyk D. Activated carbon in sediment remediation. Benefits, risks and perspectives. doctoral dissertation. Wageningen, The Netherlands: Wageningen University; 2013.

59. Lehr JH. Wiley's remediation technologies handbook: major contaminant chemicals and chemical groups. Hoboken: WileyInterscience; 2004.

60. Leij FJ, Alves WJ, van Genuchten MTh, Williams JR. Unsaturated soil hydraulic database, UNSODA 1.0 user's manual. Report EPA/600/R-96/095. EPA, Ada, OK. 1996.

61. Lin D, Cho Y, Werner D, Luthy RG. Bioturbation delays attenuation of DDT by clean sediment cap but promotes sequestration by thin-layered activated carbon. Environ Sci Technol. 2014;48: 1175-83.

62. Lojková L, Vranová V, Rejšek K, Formánek P. Natural occurrence of enantiomers of organic compounds versus phytoremediations: should research on phytoremediations be revisited? Chirality. 2014;26:1-20.

63. Long ER, MacDonald DD, Smith SL, Calder ED. Incidence of adverse biological effects within ranges of chemical concentrations in marine and estuarine sediments. Environ Manag. 1995;19:81-97.

64. Long GR, Ayers MA, Callender E, Van Metre PC. Trends in chemical concentration in sediment from three lakes in New Jersey and one lake on Long Island, New York. U.S. Geological Survey Report 02-4272. West Trenton, New Jersey; 2003.

65. Lunney AI, Zeeb BA, Reimer KJ. Uptake of weathered DDT in vascular plants: potential for phytoremediation. Environ Sci Technol. 2004;38(22):6147-54.

66. Millward R, Bridges T, Ghosh U, Zimmerman J, Luthy R. Addition of activated carbon to sediments to reduce PCB bioaccumulation by a polychaete (Neanthes arenaceodentata) and an amphipod (Leptocheirus plumulosus). Environ Sci Technol. 2005;39:2880-7.

67. Montgomery W. Summary report: sediment removal demonstration project, sediment management unit 56/57, Fox River, Green Bay, Wisconsin; 2000.

68. Nadeau SC, Erickson MJ. Surviving in the next frontier: a perspective on key sediment issues. Michigan Air \& Waste Association Annual Conference Proceedings. 2002.

69. Nadeau SC, McCulloch MC. Effective communication with stakeholders concerning remedial options for sediment sites. 6th International Conference Proceedings on Remediation of Contaminated Sediments, New Orleans, Louisiana; 2011.

70. Nash RG, Harris WG, Lewis CC. Soil pH and metallic amendment effects on DDT conversion to DDE. J Environ Qual. 1973;2: 390-4. 
71. National Wildlife Federation. Big Sunflower River dredging and Yazoo backwater pump-Mississippi. Factsheet. 2008.

72. National Research Council. Sediment dredging at superfund megasites: assessing the effectiveness. Washington, D.C.: The National Academies Press; 2007.

73. Nichols M, Diaz RJ, Schaffner LC. Effects of hopper dredging and sediment dispersion, Chesapeake Bay. Environ Geol Water Sci. 1990;15:31-43.

74. Olsta JT, Hornaday CJ, Darlington JW. Reactive material options for in situ capping. J ASTM Int. 2006;3(6):248-53.

75. Ouyang Y, Nkedi-Kizza P, Mansell RS, Ren JY. Spatial distribution of DDT in sediments from estuarine rivers of central Florida. J Environ Qual. 2003;32:1710-6.

76. Parween M, Ramanathan AL, Khillare PS, Raju NJ. Persistence, variance and toxic levels of organochlorine pesticides in fluvial sediments and the role of black carbon in their retention. Environ Sci Pollut Res. 2014;21:652546.

77. Perelo LW. Review: in situ and bioremediation of organic pollutants in aquatic sediments. J Hazard Mater. 2010;177(2010):81-9.

78. Phillips PJ, Riva-Murray K, Hollister HM, Flanary EA. Distribution of DDT, chlordane, and total PCB's in bed sediments in the Hudson River Basin. N Y Earth Sci Environ. 1997;3(1):2647.

79. Pirnie EF, Talley JW, Hundal LS. Abiotic transformation of DDT in aqueous solutions. Chemosphere. 2006;65:1576-82.

80. Quensen JF, Mueller SA, Jain MK. Reductive dechlorination of DDE to DDMU in marine sediment microcosms. Science. 1998;280:722-4.

81. Randall PM, Chattopadhyay S. Mercury contaminated sediment sites - an evaluation of remedial options. Environ Res. 2013;125: 131-49.

82. Renner R. Natural remediation of DDT, PCBs Debated. Environ Sci Technol. 1998;32(15):360A-3.

83. Rock S. Potential for phytoremediation of contaminated sediments. National Conference on Management and Treatment of Contaminated Sediments. EPA/625/R-98/001; 1998. p. 101-105.

84. Ruus A, Green NW, Maage A, Amundsen CE, Schøyena M, Skei J. Post World War II orcharding creates present day DDTproblems in The Sørfjord (Western Norway) - a case study. Mar Pollut Bull. 2010;60:1856-61.

85. Satapanajaru T, Anurakpongsatorn P, Songsasen A, Boparai H, Park J. Using low-cost iron byproducts from automotive manufacturing to remediate DDT. Water Air Soil Pollut. 2006;175(1-4):361-74.

86. Sayles GD, You G, Wang M, Kupferle MJ. DDT, DDD, and DDE dechlorination by zero-valent iron. Environ Sci Technol. 1997;31: 3448-54.

87. Schaanning M, Breyholtz B, Skei J. Experimental results on effects of capping on fluxes of persistent organic pollutants (POPs) from historically contaminated sediments. Mar Chem. 2006;102: 46-59.

88. Schultz T, Korhonen P, Virtanen M. A mercury model used for assessment of dredging impacts. Water Air Soil Pollut. 1995;80: 1171-80.

89. Sediment Focus Group. Sediment remedy effectiveness and recontamination: selected case studies. The association of state and territorial solid waste management officials. Washington, D.C.: CERCLA and Brownfields Research Center; 2013.

90. Serdar D, Era-Miller B. DDT contamination and transport in the lower Mission Creek Basin, Chelan County, total maximum daily load assessment. Olympia, Washington: Washington State Department of Ecology; 2004. Publication No. 04-03-043.

91. Sherwood CR, Drake DE, Wiberg PL, Wheatcroft RA. Prediction of the Fate of $\mathrm{p}, \mathrm{p}$-DDE in sediment on the
Palos Verdes Shelf, California, USA. Cont Shelf Res. 2002;22(6):1025-58.

92. Shields FD, Knight SS. Pre-restoration assessment, Big Sunflower River, Mississippi: where to begin? Proceedings of the World Environmental and Water Resources Congress: Reston, Virginia. 2010. p. 1777-1787.

93. Shin Y-O, Chodan JJ, Wolcott AR. Adsorption of DDT by soils, soil fractions, and biological materials. J Agric Food Chem. 1970;18(6):1129-33.

94. Sibali LL, Okonkwo JO, Zvinowanda C. Determination of DDT and metabolites in surface water and sediment using LLE, SPE, ACE and SE. Bull Environ Contam Toxicol. 2009;83:885-91.

95. Singh SP, Bose P, Guha S, Gurjar SK, Bhalekar S. Impact of addition of amendments on the degradation of DDT and its residues partitioned on soil. Chemosphere. 2013;92(7):811-20.

96. Sittig M. Priority toxic pollutants - health impacts and allowable limits. Park Ridge: Noyes Data Corporation; 1980.

97. Skeo Solutions. Five-year review report third five-year review report for Ciba-Geigy Corporation (McIntosh Plant). Washington County: McIntosh; 2011.

98. Sudharshan S, Naidu R, Mallavarapu M, Bolan N. DDT remediation in contaminated soils: a review of recent studies. Biodegradation. 2012;23:851-63.

99. Tetra Tech. Treatability study for select sediment cap materials for site 102 - Abraham's Creek, Marine Corps Base Quantico. Virginia: Naval Facilities Engineering Command Washington; 2014.

100. Van Den Berg GA, Meijers GGA, Van Der Heijdt LM, Zwolsman JJG. Dredging-related mobilisation of trace metals: a case study in the Netherlands. Water Res. 2001;35:1979-86.

101. van den Hoop MAGT, Kreule P, Gustav Loch JP. Sorption kinetics and transformation of DDT in sediment. Water Air Soil Pollut. 1999;110(1-2):57-66.

102. Van Deuren J, Lloyd T, Chhetry S, Liou R, Peck J. Remediation technologies screening matrix and reference guide. 4th Edition. Federal Remediation Technology Roundtable. SFIM-AEC-ETCR-97053. 2006.

103. Veljanoska-Sarafiloska EM, Stafilov T. Comparison of the presence of DDT metabolites in sediments and fish from Lakes Ohrid, Prespa and Dojran. Acta Zool Bulg. 2009;4:215-22.

104. Verstraeten IM, Heberer T, Scheytt T. Occurrence, characteristics, transport, and fate of pesticides, pharmaceuticals, industrial products, and personal care products at riverbank filtration sites. In: Ray C, Melin G, Linsky RB, editors. Riverbank Filtration: Improving Source-Water Quality. New York: Kluwer Academic Publishers; 2003. p. 175-228.

105. Wang Q, Kim D, Dionysiou DD, Sorial GA, Timberlake D. Sources and remediation for mercury contamination in aquatic systems - a literature review. Environ Pollut. 2004;131:323-36.

106. Weston DP, Jarman WM, Cabana G, Bacon CE, Jacobson LA. An evaluation of the success of dredging as remediation at a DDTcontaminated site in San Francisco Bay, California, USA. Environ Toxicol Chem. 2002;21(10):2216-24.

107. White JC, Mattina MI, Eitzer BD, Isleyen M, Parrish ZD, Gent MPN. Enhancing the uptake of weathered persistent organic pollutants by Cucurbita pepo. The Third International Phytotechnologies Conference Proceedings, Atlanta, Georgia; 2005.

108. WHO. Environmental health criteria 83, DDT and its derivatives and environmental effects. Geneva: World Health Organization; 1989.

109. Xia C, Ma X, Liu S, Fanc P. Studies on remediation of DDTcontaminated soil and dechlorination of DDT. Procedia Environ Sci. 2012;16:289-92.

110. Xing B, Pignatello JJ. Dual-mode sorption of low-polarity compounds in glassy poly(vinyl chloride) and soil organic matter. Environ Sci Technol. 1997;31:792-9. 
111. Yavari S, Malakahmad A, Sapari NB. Biochar efficiency in pesticides sorption as a function of production variables - a review. Environ Sci Pollut Res. 2015;22:13824-41.
112. Yue Q, Zhang K, Zhang B, Li S, Zeng EY. Occurrence, phase distribution and depositional intensity of dichlorodiphenyltrichloroethane (DDT) and its metabolites in air and precipitation of the Pearl River Delta, China. Chemosphere. 2011;84(4):446-51. 